\title{
Cardiovigilance in Atrial Fibrillation - Primordial to Quinary Prevention Intervention
}

\author{
Kamal Kishor, ${ }^{1}$ Devendra Bisht, ${ }^{2}$ Sanjay Kalra ${ }^{3}$
}

1. Department of Cardiology, Rama Hospital, Karnal, India; 2. Department of Cardiology, Mayo Hospital, Mohali, India;

3. Department of Endocrinology, Bharti Hospital, Karnal, India

A trial fibrillation (AF) is one of the major causes of stroke, heart failure, sudden death and cardiovascular morbidity in the world. Management of AF, its risk factors and complications demands huge cost. The frequent hospitalisations, haemodynamic abnormalities, and thromboembolic events related to AF put a huge emotional and monetary burden on patients, so preventive strategies will be a cost-effective means of reducing this burden. Primordial prevention (i.e., intervention prior to onset of disease risk factors) should be implemented by the government, along with the food industry, to educate the public regarding the importance of a healthy diet and adherence to it. Primary prevention should focus on halting the onset of AF in targeted populations who carry risk factors for development of AF. The strategy at the secondary-prevention level includes optimal control of rate or rhythm either by anti-arrhythmic drugs or catheter ablation. Every effort should be made to reduce the incidence of ischaemic stroke by using optimal oral anticoagulation, devices or surgical closure of left atrial appendage. Tertiary level prevention should focus on the management of complications incurred as a result of AF, such as ischaemic stroke, heart failure or asymptomatic left ventricular dysfunction. Since management of AF demands a huge economic burden and the line between thrombotic complications and bleeding complications is a thin one; over-diagnosis and overtreatment of AF should be avoided. The ultimate aim of quinary prevention is to sensitise the physician to follow evidence-based medicine and to get rid of populated myth. This current review summarises a stepwise preventive strategy for AF from the primordial level to the quinary level.

\section{Keywords}

Atrial fibrillation, cardiovigilance, prevention

Disclosure: Kamal Kishor, Devendra Bisht, Sanjay Kalra have nothing to disclose in relation to this article.

Review Process: Double-blind peer review.

Compliance with Ethics: This study involves a review of the literature and did not involve any studies with human or animal subjects performed by any of the authors.

Authorship: The named authors meet the International Committee of Medical Journal Editors (ICMJE) criteria for authorship of this manuscript, take responsibility for the integrity of the work as a whole, and have given final approval for the version to be published.

Received: 21 January 2019

Accepted: 15 April 2019

Citation: European Journal of Arrhythmia

\& Electrophysiology. 2019;5(2):77-81

Corresponding Author: Sanjay Kalra,

Department of Endocrinology, Bharti Hospital

Karnal 132001 India. E: brideknl@gmail.com

Support: No funding was received for

the publication of this article.
Long-term follow-up of patients with atrial fibrillation (AF) has confirmed a significant increase in cardiovascular events, long-term risk of stroke, heart failure and all-cause mortality (89\% in those with AF compared to $27 \%$ in those without AF). ${ }^{1}$ Not only is AF associated with a five-fold increased risk of stroke, AF-related stroke is also likely to be more severe than non-AF-related stroke., ${ }^{2,3}$ $\mathrm{AF}$ is associated with a three-fold risk of heart failure ${ }^{4-6}$ and a two-fold increased risk of both dementia7 and mortality. ${ }^{8}$ Since AF is associated with multiple modifiable risk factors, prevention strategies should begin right from the primordial level. Stepwise strategies are discussed in this current review (Table 1).

\section{Primordial prevention}

In the context of this article, the term 'primordial' is representative of early intervention prior to the onset of risk factors that precede disease. The goal of primordial prevention may be achieved by lifestyle modification. This aims to halt the development of modifiable risk factors (Table 2) that can set the stage for development of AF. The STRIP (the Special Turku Coronary Risk Factor Intervention Project for Children) trial investigated the effect of primordial level intervention by providing healthy fats; more fruits, vegetables and whole grains; and less sodium to selected populations from infancy to adolescents, on the prevalence of metabolic syndrome.? STRIP Investigators recommended limiting salt intake, substituting unsaturated for saturated fats and promoting healthier foods starting in infancy and toddlerhood in order to help achieve ideal cardiovascular health. These recommendations were based on the fact that healthier outcomes were primarily driven by reduction of high blood pressure in both sexes and high triglyceride in boys. The government, along with the food industry, should help educate the public regarding the importance of a healthy diet and how to adhere to it. The co-operation of the food industry is required to achieve significant reductions in sodium intake.

\section{Primary prevention}

Analysis of the original Framingham Heart Study cohort has concluded that the risk factors for cardiovascular disease also predispose to AF.10 The authors confirmed the statistically significant association of diabetes (odds ratio [OR] 1.4 for men and 1.6 for women), hypertension (OR 1.5 for men and 1.4 for women) and congestive heart failure (OR 4.5 for men and 5.9 for women), with development of $\mathrm{AF}$ in both sexes..$^{10}$ Optimal control and modification of these risk factors 
Table 1: Preventive strategy in atrial fibrillation

\begin{tabular}{|c|c|c|}
\hline Prevention level & Parameter & Intervention \\
\hline $\begin{array}{l}\text { Primordial } \\
\text { prevention }\end{array}$ & $\begin{array}{l}\text { Prevention of risk factors } \\
\text { for } \mathrm{AF}\end{array}$ & $\begin{array}{l}\text { Healthy lifestyle, low-salt } \\
\text { diet, increased fruit intake, } \\
\text { increased physical activity }\end{array}$ \\
\hline Primary prevention & Prevention of onset of AF & $\begin{array}{l}\text { Weight reduction, optimal } \\
\text { control of hypertension, } \\
\text { optimal control of diabetes } \\
\text { and endocrine disorder }\end{array}$ \\
\hline $\begin{array}{l}\text { Secondary } \\
\text { prevention }\end{array}$ & $\begin{array}{l}\text { Early diagnosis and } \\
\text { prevention of complication } \\
\text { secondary to AF }\end{array}$ & $\begin{array}{l}\text { Holter monitoring in case of } \\
\text { paroxysmal AF }\end{array}$ \\
\hline Tertiary prevention & $\begin{array}{l}\text { Rehabilitation: heart failure } \\
\text { and post thromboembolic } \\
\text { events }\end{array}$ & $\begin{array}{l}\text { Adequate rate control or } \\
\text { rhythm control; } \\
\text { Optimal OAC }\end{array}$ \\
\hline $\begin{array}{l}\text { Quaternary } \\
\text { prevention }\end{array}$ & $\begin{array}{l}\text { Prevention of } \\
\text { overdiagnosis of AF; } \\
\text { Prevention of } \\
\text { complications secondary } \\
\text { to over-treatment }\end{array}$ & $\begin{array}{l}\text { Careful analysis of rhythm; } \\
\text { Bleeding risk evaluation } \\
\text { before OAC }\end{array}$ \\
\hline Quinary prevention & $\begin{array}{l}\text { Under- or over-treatment } \\
\text { because of myths related } \\
\text { to the concerned disease }\end{array}$ & $\begin{array}{l}\text { Promoting evidence-based } \\
\text { management }\end{array}$ \\
\hline
\end{tabular}

$A F=$ atrial fibrillation; $O A C=$ oral anticoagulant.

Table 2: Risk factors and intervention at primordial level for atrial fibrillation

\begin{tabular}{|l|l|}
\hline Risk factors & Intervention at primordial level \\
\hline Modifiable risk factors & Healthy lifestyle \\
\hline Hypertension & Low-salt diet \\
Diabetes mellitus & Increase fruit intake \\
Heart failure & Increase physical activity \\
Obstructive heart failure & Substitute polyunsaturated fatty acid \\
Myocardial infarction & for saturated fat \\
Chronic obstructive pulmonary disease & \\
Chronic kidney disease & \\
Smoking & \\
Alcohol consumption & \\
Thyroid dysfunction & \\
\hline Non-modifiable risk factors & \\
\hline $\begin{array}{l}\text { Age } \\
\text { Genetic }\end{array}$ & \\
\hline
\end{tabular}

may substantially reduce the onset of AF. Intervention in these groups of patients may be in the form of angiotensin converting enzyme (ACE) inhibitors/angiotensin receptor blockers (ARB) and statins. As AF is one of the major causes of stroke, heart failure, sudden death and cardiovascular morbidity in the world, ${ }^{11}$ intervention to prevent the onset of $\mathrm{AF}$ in this target population will be a cost-effective means of reducing further burden (Table 3).

\section{Secondary prevention}

AF worsens quality of life and can cause a statistically significant increase in the risk of cardiovascular events (death, heart failure, stroke and sudden cardiac death). ${ }^{11}$ To prevent complications associated with $A F$, secondary prevention strategy is discussed in the following sections.
Table 3: Example of intervention at primary prevention level in patients with atrial fibrillation

\begin{tabular}{|l|l|l|}
\hline Target & Intervention & Outcome \\
\hline $\begin{array}{l}\text { Diabetes } \\
\text { mellitus }\end{array}$ & $\begin{array}{l}\text { Good glycaemic control; } \\
\text { Upfront therapy: } \\
\text { ACEI/ARB/Statin }\end{array}$ & $\begin{array}{l}\text { Prevent atrial remodelling; } \\
\text { Upfront therapy may help } \\
\text { in preventing remodelling } \\
\text { of atria }\end{array}$ \\
\hline Hypertension & $\begin{array}{l}\text { Adequate rate control; } \\
\text { Standard treatment for heart } \\
\text { failure }\end{array}$ & $\begin{array}{l}\text { Prevent atrial remodelling; } \\
\text { Reduce the incidence of AF }\end{array}$ \\
\hline Heart failure & $\begin{array}{l}\text { Anti-remodelling therapy in } \\
\text { form of ACEI/betablockers; } \\
\text { Optimal control of filling } \\
\text { pressure by diuretics }\end{array}$ & $\begin{array}{l}\text { Betablocker; } \\
\text { ACE/ARB }\end{array}$ \\
\hline $\begin{array}{l}\text { Coronary } \\
\text { artery disease }\end{array}$ & $\begin{array}{l}\text { Timely revascularisation and } \\
\text { optimal medical treatment to } \\
\text { preserve geometry of LV }\end{array}$ & $\begin{array}{l}\text { Betablocker/CCB; } \\
\text { Rhythm control strategy }\end{array}$ \\
\hline
\end{tabular}

$A C E I=$ angiotensin converting enzyme inhibitor; $A F=$ atrial fibrillation; $A R B=$ angiotensin receptor blocker; $C C B=$ calcium channel blocker; $L V=$ left ventricle.

\section{Lifestyle modification}

Lifestyle modification in the form of smoking cessation, good quality sleep, alcohol cessation, incorporation of a Mediterranean diet, physical activity in any form and yoga are beneficial in the management of $A F^{12}$ Lifestyle intervention not only reduces the incidence of $A F$, but also induces $A F$ remission and more successful ablation outcomes. ${ }^{12}$ Even if one may not able to completely reverse AF with lifestyle modification, intervention at the lifestyle level may likely enhance AF treatment efficacy. ${ }^{12}$

\section{Optimisation of rate control of and normal sinus rhythm}

Restoring and maintaining sinus rhythm should be an integral part of AF management. Antiarrhythmic drugs approximately double the rate of sinus rhythm compared with placebo. ${ }^{13-7}$ The effect of modern rhythm control management using catheter ablation, combination therapy, or early catheter ablation on major cardiovascular events is still under investigation. ${ }^{6.18}$ Catheter ablation may be considered as a second-line treatment (after failure of, or intolerance to, antiarrhythmic drug therapy) in restoring and maintaining sinus rhythm in patients with symptomatic paroxysmal, persistent and probably long-standing persistent AF. ${ }^{19-22}$ However, catheter ablation should not be used to prevent cardiovascular outcomes, to withdraw anticoagulant, or to reduce hospitalisations. ${ }^{18}$ AF catheter ablation has also shown promising results in heart failure with reduced left ventricular ejection fraction in terms of lower mortality rate and reduce hospitalisation for heart failure, especially in patients without prior myocardial infarction. ${ }^{18}$ However, since ablating AF can be demanding in these patients, selection of patients should be carefully balanced and the procedures should be performed in experienced centres only.

Fast ventricular rate in AF demands rate control on a priority basis. One must look for and treat the precipitating cause (anaemia, alcohol intake, pulmonary embolism, infection, hyperthyroidism, drug use, acute coronary syndrome, valvular heart disease etc). Rapid rate control during AF may be achieved by intravenous diltiazem/verapamil; both of which have rapid onset of action and are effective at high sympathetic tone. ${ }^{23,24}$ Other agents that may be used for rate control in specific conditions are beta blockers, digoxin (heart failure with AF) and amiodarone (AF with severe left ventricular systolic dysfunction). 
Table 4: Intervention as secondary prevention strategy

\begin{tabular}{|c|c|c|}
\hline Target & Intervention & Outcome \\
\hline $\begin{array}{l}\text { Fast ventricular rate: } \\
\text { Rate control strategy }\end{array}$ & $\begin{array}{l}\text { Digoxin; } \\
\text { Betablocker; } \\
\text { Calcium channel blockers } \\
\text { (Diltiazem/Verapamil) }\end{array}$ & $\begin{array}{l}\text { Symptomatic relief; } \\
\text { Improved tachycardia } \\
\text { induced LV dysfunction }\end{array}$ \\
\hline \multirow{2}{*}{$\begin{array}{l}\text { Fast ventricular rate } \\
\text { Rhythm control } \\
\text { strategy }\end{array}$} & $\begin{array}{l}\text { Structural heart disease; } \\
\text { Amiodarone }\end{array}$ & \multirow{2}{*}{$\begin{array}{l}\text { Symptomatic relief; } \\
\text { Improved tachycardia } \\
\text { induced LV dysfunction; } \\
\text { Reduced incidence of } \\
\text { stroke }\end{array}$} \\
\hline & $\begin{array}{l}\text { No structural heart disease; } \\
\text { Amiodarone/flecainide/ } \\
\text { propafenone/ibutilide/ } \\
\text { vernakalant }\end{array}$ & \\
\hline Anticoagulation & $\begin{array}{l}\text { VKAS; } \\
\text { NOACS } \\
\text { (Dabigatarn/rivaroxaban/ } \\
\text { apixaban/endoxaban) }\end{array}$ & $\begin{array}{l}\text { Reduced incidence of } \\
\text { stroke }\end{array}$ \\
\hline \multirow[t]{2}{*}{ Invasive approach } & Pulmonary vein isolation & $\begin{array}{l}\text { Refractory and } \\
\text { symptomatic AF }\end{array}$ \\
\hline & Watchman device & $\begin{array}{l}\text { Less stroke in population } \\
\text { at high risk of bleeding } \\
\text { with VKAs/NOACs }\end{array}$ \\
\hline
\end{tabular}

$A F=$ atrial fibrillation; $L V=$ left ventricle; NOACS = novel oral anticoagulants; $V K A S=$ vitamin $\mathrm{K}$ antagonists.

Since clinical events, NYHA class, or hospitalisations rates among patients with lenient heart rate control (target of $110 \mathrm{bpm}$ ) are as good as strict heart rate control, ${ }^{25}$ either of the strategies may be used while opting for a rate-control strategy over rhythm-control strategy.

\section{Achievement of adequate anticoagulation}

Adequate anticoagulation should be achieved to minimise the risk of thromboembolic events in the setting of AF. The CHA2DS2-VASC score is widely used as a risk stratification tool for the initial decision to start oral anticoagulants in patients with AF. Patients with score of 0 (i.e., without any clinical stroke risk factors) do not need oral-anticoagulant therapy; while patients with CHA2DS2-VASc score of $>1$ in men, and $>2$ in women, need to be on oral anticoagulants to prevent ischaemic stroke. ${ }^{26}$ Bleeding risk must be assessed before starting oral anticoagulants. Notably, many of the risk factors for stroke and bleeding overlap with each other. Aspirin as monotherapy has no benefit for stroke prevention in patients of $\mathrm{AF}^{27}$ Antiplatelet monotherapy therefore is not recommended for stroke prevention in patients with $A F$, irrespective of their stroke risk. Dual antiplatelet therapy offers significantly less protection against stroke, thromboembolism, myocardial infarction and vascular deaths when compared to vitamin $\mathrm{K}$ antagonists (VKAs; annual risk of 5.6\% for aspirin and clopidogrel versus $3.9 \%$ with VKA therapy) but at the cost of similar bleeding risk $(2.0 \%$ versus $1.3 \%$ with antiplatelet monotherapy; $p=0.001) .{ }^{28} \mathrm{HASBLED}$, ORBIT and $A B C$ are three bleeding risk scores that have been developed for risk assessment of bleeding in patients on VKAs. ${ }^{29-31} \mathrm{~A}$ high bleeding score should not be a reason to defer oral anticoagulants; rather one should identify and treat the underlying risk factors.

\section{Left atrial appendage closure device}

Left atrial appendage closure may be considered for patients with contraindication to long-term oral anticoagulants. Left atrial appendage occlusion has been found non-inferior to VKA treatment for the prevention of stroke in AF patients with moderate stroke
Table 5: Tertiary level prevention in patient with atrial fibrillation

\begin{tabular}{|l|l|l|}
\hline Complications & Intervention & Outcome \\
\hline $\begin{array}{l}\text { Thromboembolic } \\
\text { complications } \\
\text { (repeat stroke/ } \\
\text { peripheral or } \\
\text { pulmonary } \\
\text { embolism) }\end{array}$ & $\begin{array}{l}\text { Achieve adequate OAC } \\
\text { i. Warfarin/Acitrome } \\
\text { ii. NOACs } \\
\text { iii. Watchman device }\end{array}$ & $\begin{array}{l}\text { Reduce incidence of } \\
\text { recurrent thromboembolic } \\
\text { complication }\end{array}$ \\
\hline $\begin{array}{l}\text { Acute } \\
\text { decompensated } \\
\text { heart failure }\end{array}$ & $\begin{array}{l}\text { Pharmacological/DC } \\
\text { cardioversion; } \\
\text { Digoxin; } \\
\text { Betablocker; } \\
\text { Diuretics; } \\
\text { Aldosterone antagonist }\end{array}$ & $\begin{array}{l}\text { Improvement in reversible } \\
\text { LV dysfunction; } \\
\text { Improvement in } \\
\text { cardiovascular outcomes; } \\
\text { Improved NYHA Class }\end{array}$ \\
\hline $\begin{array}{l}\text { Asymptomatic LV } \\
\text { dysfunction }\end{array}$ & $\begin{array}{l}\text { Betablocker; } \\
\text { ACE/ARB; } \\
\text { Diuretics; } \\
\text { Aldosterone antagonist }\end{array}$ & $\begin{array}{l}\text { Improvement in reversible } \\
\text { LV dysfunction; } \\
\text { Improvement in } \\
\text { cardiovascular outcomes; } \\
\text { Improved NYHA Class }\end{array}$ \\
\hline
\end{tabular}

$A C E$ = angiotensin converting enzyme; $A R B=$ Angiotensin receptor blocker; $D C=$ direct current; $L V=$ left ventricle; $N O A C=$ non vitamin $K$ antagonists; $N Y H A=$ New York Heart Association; OAC = oral anticoagulant .

risk, with a possibility of lower bleeding rates in the patients. Three studies have focused on left atrial appendage closure in patients with contraindications to oral-anticoagulant therapy and have shown improvement in the incidence of ischaemic stroke from expected 5.6-7.6\% (based on $\mathrm{CHADS}_{2}$ score) to $1.7-3.2 \%{ }^{32-4}$ Surgical exclusion of left atrial appendage did not show a clear benefit of left atrial appendage exclusion for stroke prevention in a subgroup undergoing AF surgery. ${ }^{35}$ Some of the steps to intervene at secondary level and their outcomes are mentioned in Table 4.

\section{Tertiary prevention}

Tertiary prevention addresses the care of patients who have already suffered a stroke/transient ischaemic attack (Table 5). These measures are aimed at the prevention of a second or third stroke and reducing the disability through patient rehabilitation. Research shows that patients who suffer recurrent stroke have poorer outcomes than those who suffer a first stroke; ${ }^{36}$ hence, anticoagulation is the major goal of therapy in patients with AF. The Stroke Prevention Patient Outcomes Research Team (PORT) study found that 57\% of patients with a first stroke survived 24 months after their stroke, compared with $48 \%$ of those who had a recurrent stroke..$^{37}$ Patients with AF with a mechanical prosthetic valve, moderate to severe mitral stenosis, or those with advanced kidney disease $(\mathrm{CrCl}<30 \mathrm{~mL} / \mathrm{min})$, should be treated exclusively with VKAs.

Multiple randomised controlled trials have demonstrated non-inferiority/superiority of novel oral anticoagulants (NOACs; dabigatran, rivaroxaban, apixaban and edoxaban) in non-valvular AF as compared to VKAs. ${ }^{38-42}$ Also, since each anticoagulant carries risks for haemorrhagic complications, it is useful to risk-stratify patients with AF to identify appropriate candidates for anticoagulation.

\section{Quaternary prevention}

Quaternary prevention is an emerging concept that cautions against overdiagnosis and overtreatment of the disease (Table 6). 
Table 6: Quaternary prevention in atrial fibrillation

\begin{tabular}{|c|c|c|}
\hline Target & Intervention & Outcome \\
\hline Overdiagnosis of AF & Careful examination of ECG before labelling AF & Proper diagnosis of AF \\
\hline Over-prescription of OACS & CHA2DS2-VASC score for identification of targeted population & $\begin{array}{l}\text { Reduced hospitalisation } \\
\text { Less unnecessary OAC } \\
\text { Less bleeding }\end{array}$ \\
\hline $\begin{array}{l}\text { Bleeding complication with } \\
\text { OACs }\end{array}$ & $\begin{array}{l}\text { CHA2DS2-VASC of score for identification of targeted population } \\
\text { HAS-BLED Score to balance need of OAC } \\
\text { Regular monitor of INR } \\
\text { Patient education regarding diet interaction in VKAS } \\
\text { Dose adjustment after introduction of interacting drug (amiodarone/digoxine) }\end{array}$ & Less bleeding \\
\hline Drug toxicity & $\begin{array}{l}\text { Digoxin } \\
\text { Dose adjustment as per patient profile/renal function } \\
\text { Planned drug holiday } \\
\text { Dose adjustment after introduction of interacting drug (amiodarone/warfarin) } \\
\text { Serum digoxin level } \\
\text { Amiodarone } \\
\text { Regular monitoring of LFT/thyroid and PFT } \\
\text { Regular monitoring of QTC } \\
\text { VKAS } \\
\text { Risk assessment before initiation of OACS } \\
\text { Protocol based INR checking } \\
\text { Consideration of drug interaction }\end{array}$ & Improved quality of life due to fewer side effects \\
\hline
\end{tabular}

$A F=$ atrial fibrillation; $E C G=$ electrocardiogram; INR = international normalised ratio; $L F T=$ liver function test; OAC = oral anticoagulant; $P F T=$ pulmonary function test; $\mathrm{QTC}=\mathrm{QT}$ interval; $\mathrm{VKA}=$ vitamin $\mathrm{K}$ antagonist.

Table 7: Common myths and facts related to atrial fibrillation

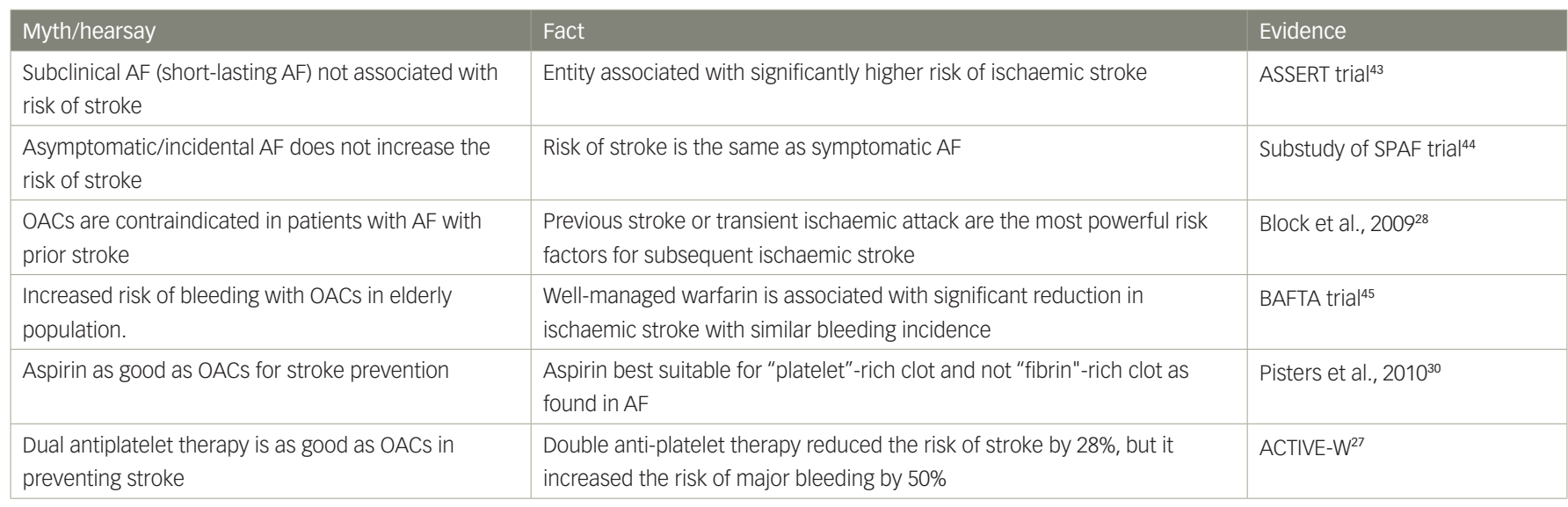

$A F=$ atrial fibrillation; $O A C=$ oral anticoagulant.

A few of the considerations relevant to quaternary prevention are highlighted below as quaternary prevention of AF. Careful evaluation and interpretation of the underlying rhythm is of utmost importance. Treatment must be planned after considering the frequency and type of $A F$, underlying aetiology and associated risk factors. Over-prescription of oral anticoagulants must be avoided. One must balance between thrombotic risk associated with AF and bleeding risk due to oral anticoagulants.

\section{Overdiagnosis of atrial fibrillation}

Many tachyarrhythmias may mimic AF. Attention should be given to regularity and rate. Atrial premature complexes, junctional ectopic tachycardias, ventricular premature complexes and sinus arrhythmia are the common mimickers of AF. Careful analysis of the rhythm and the presence of well-formed $\mathrm{P}$ wave may help one to rule out the possibility of AF.

\section{Overtreatment of atrial fibrillation}

Patients with AF are more likely to suffer stroke compared to those without $\mathrm{AF}_{\text {, }}^{2,3}$ making oral anticoagulants (VKAs or NOACS) mandatory in patients with AF whenever the risk of stroke is high. However, one must balance the benefit of oral anticoagulants with risk of bleeding related to this class of therapy. CHA2DS2-VASC and HASBLED scores are available tools to justify initiation of oral anticoagulation. VKA treatment should further be monitored regularly by international normalised ratio (INR), keeping it in range of 2.0-3.0. The spectrum of overtreatment with various classes of therapy varies from gastrointestinal symptoms (nausea, vomiting or abdominal pain), thyroid dysfunction, abnormal pulmonary function test or bradycardia-induced syncope. Careful follow-up with intermittent treatment holidays may prevent such complications. Intervention at quaternary level related to AF management has been highlighted in Table 6 . 


\section{Quinary prevention}

Quinary prevention deals with popular myths related to the concerned disease (Table 7). ${ }^{27,28,30,43-5}$ Quinary prevention is a new concept which has gained traction with the development of information technology and social media. A few examples are:

- asymptomatic/incidental AF does not increase the risk of stroke;

- oral anticoagulants are contraindicated in patients with AF with prior stroke; and

- there is an increased risk of bleeding with oral anticoagulants in elderly populations.

\section{Summary}

$\mathrm{AF}$ is a preventable disease and so are its complications. This review provides advice regarding the various methods for the prevention of $\mathrm{AF}$ and its related complications. The format described here is easy to understand and apply; it also enhances the appeal of preventive measures and underscores the need to integrate them in routine public health programmes, medical and cardiology practice. $\square$
1. Andersson T, Magnuson A, Bryngelsson IL, et al. All-cause mortality in 272,186 patients hospitalized with incident atria fibrillation 1995-2008: a Swedish nationwide long-term case- control study. Eur Heart J. 2013;34:1061-7.

2. Wolf PA, Abbott RD, Kannel WB. Atrial fibrillation as an independent risk factor for stroke: the Framingham Study. Stroke. 1991:22:983-8.

3. Hannon N, Sheehan O, Kelly L, et al. Stroke associated with atrial fibrillation - incidence and early outcomes in the North Dublin Population Stroke Study. Cerebrovasc Dis. 2010;29:43-9.

4. Hart RG, Pearce LA, Aguilar MI. Meta-analysis: Antithrombotic therapy to prevent stroke in patients who have nonvalvular atrial fibrillation. Ann Intern Med. 2007;146:857-67.

5. Ruff $\mathrm{CT}$, Giugliano RP, Braunwald E, et al. Comparison of the efficacy and safety of new oral anticoagulants with warfarin in patients with atrial fibrillation: a meta-analysis of randomised trials. Lancet. 2014;383:955-62.

6. Kirchhof P, Breithardt G, Camm AJ, et al. Improving outcomes in patients with atrial fibrillation: rationale and design of the Early treatment of Atrial fibrillation for Stroke prevention Trial. Am Heart J. 2013;166:442-8.

7. Al-Khatib SM, Allen LaPointe NM, Chatterjee R, et al. Rate- and rhythm-control therapies in patients with atrial fibrillation: a systematic review. Ann Intern Med. 2014;160:760-73.

8. Kirchhof P, Schmalowsky J, Pittrow D, et al. Management of patients with atrial fibrillation by primary care physicians in Germany: 1-year results of the ATRIUM registry. Clin Cardiol. 2014;37:277-84.

9. Pahkala $\mathrm{K}$, Hietalampi $\mathrm{H}$, Laitinen $\mathrm{TT}$, et al. Ideal cardiovascular health in adolescence: effect of lifestyle intervention and association with vascular intima-media thickness and elasticity (the Special Turku Coronary Risk Factor Intervention Project for Children [STRIP] study). Circulation. 2013;127:2088-96.

10. Benjamin EJ, Levy D, Vaziri SM, et al. Independent risk factors for atrial fibrillation in a population-based cohort. The Framingham Heart Study. JAMA. 1994;271:840-4.

11. Odutayo A, Wong CX, Hsiao AJ, et al. Atrial fibrillation and risks of cardiovascular disease, renal disease, and death: systematic review and meta-analysis. BMJ. 2016;354:14482

12. Sabzwari SRA, Garg L, Lakkireddy D, Day J. Ten lifestyle modification approaches to treat atrial fibrillation. Cureus. 2018;10:e2682.

13. Lafuente-Lafuente C, Longas-Tejero MA, Bergmann JF, et al. Antiarrhythmics for maintaining sinus rhythm after cardioversion of atrial fibrillation. Cochrane Database Syst Rev. 2012;5:CD005049

14. Roy D, Talajic M, Dorian P, et al. Amiodarone to prevent recurrence of atrial fibrillation. Canadian Trial of Atrial Fibrillation Investigators. N Eng/ J Med. 2000:342:913-20

15. Roy D, Talajic M, Nattel $S$, et al. Rhythm control versus rate Control for atrial fibrillation and heart failure N Eng $\lrcorner$ Med. 2008:358:2667-77.

16. Singh BN, Connolly SJ, Crijns HJ, et al. Dronedarone for maintenance of sinus rhythm in atrial fibrillation or flutter. NEngl I Med. 2007:357:987-99.

17. Kirchhof $P$, Andresen $D$, Bosch R, et al. Short-term versus long-term antiarrhythmic drug treatment after cardioversion of atrial fibrillation (Flec-SL): a prospective, randomised, open-label, blinded endpoint assessment trial. Lancet. 2012:380:238-46.

18. Di Biase L, Mohanty P, Mohanty S, et al. Ablation vs. amiodarone for treatment of persistent atrial fibrillation in
patients with congestive heart failure and an implanted patients with congestive heart fallure and an implanted device: results from the AATAC

19. Schreiber D, Rostock T, Frohlich M, et al. Five-year follow-up after catheter ablation of persistent atrial fibrillation using the stepwise approach and prognostic factors for success Circ Arrhythm Electrophysiol. 2015;8:308-17.

20. Scherr D, Khairy P, Miyazaki S, et al. Five-year outcome of catheter ablation of persistent atrial fibrillation using termination of atrial fibrillation as a procedural endpoint. Circ Arrhythm Electrophysiol. 2015;8:18-24.

21. ClinicalTrials.gov. Catheter Ablation vs Anti-arrhythmic Drug Therapy for Atrial Fibrillation Trial (CABANA), 2018. Available at: https://clinicaltrials.gov/ct2/show/NCT00911508 (accessed 17 April 2019).

22 Mont L Bisbal F Hernandez-Madrid A et al Catheter ablation vs. antiarrhythmic drug treatment of persistent atrial fibrillation: a multicentre, randomized, controlled trial (SARA study). Eur Heart J. 2014;35:501-7.

23. Segal JB, MCNamara RL, Miller MR, et al. The evidence regarding the drugs used for ventricular rate control. J Fam Practice. 2000;49:47-59

24. Schreck DM, Rivera AR, Tricarico VJ. Emergency management of atrial fibrillation and flutter: intravenous diltiazem versus intravenous digoxin. Ann Emerg Med. 1997;29:135-40.

25. Van Gelder IC, Groenveld HF, Crijns HJ, et al. Lenient versus strict rate control in patients with atrial fibrillation. N Eng/ J Med. 2010;362:1363-73

26. Lip GY, Nieuwlaat R, Pisters R, et al. Refining clinical risk stratification for predicting stroke and thromboembolism in atrial fibrillation using a novel risk factor-based approach: the Euro Heart Survey on atrial fibrillation. Chest. 2010:137:263-72.

27. ACTIVE Writing Group of the ACTIVE Investigators, Connolly S, Pogue J, et al. Clopidogrel plus aspirin versus oral anticoagulation for atrial fibrillation in the atria fibrillation clopidogrel trial with Irbesartan for prevention of vascular events (ACTIVE W): a randomised controlled trial. Lancet. 2006;367:1903-12

28. Block PC, Burstein S, Casale PN, et al. Percutaneous left atrial appendage occlusion for patients in atrial fibrillation suboptimal for warfarin therapy: 5-year results of the PLAATO (percutaneous left atrial appendage transcatheter occlusion) study. JACC Cardiovasc Interv. 2009;2:594-600.

29. Gage BF, Yan Y, Milligan PE, et al. Clinical classification schemes for predicting hemorrhage: results from the schemes for predicting hemorinage. results from the 2006;151:713-9.

30. Pisters R, Lane DA, Nieuwlaat R, et al. A novel user- friendly score (HAS-BLED) to assess 1-year risk of major bleeding in patients with atrial fibrillation: the Euro Heart Survey. Chest. 2010;138:1093-100.

31. Fang $M C, G O A S$, Chang $Y$, et al. A new risk scheme to predict warfarin-associated hemorrhage: The ATRIA (anticoagulation and risk factors in atrial fibrillation) Study. I Am Coll Cardiol. 2011;58:395-401.

32. Gillinov AM, Gelijns AC, Parides MK, et al. Surgical ablation of atrial fibrillation during mitral-valve surgery. N Eng/ I Med. 2015;372:1399-409.

33. Reddy VY, Mobius-Winkler S, Miller MA, et al. Left atrial appendage closure with the Watchman device in patients with a contraindication for oral anticoagulation: the ASAP study (ASA Plavix feasibility study with Watchman left atrial appendage closure technology). J Am Coll Cardiol. 2013;61:2551-6

34. Tzikas A, Shakir S, Gafoor S, et al. Left atrial appendage occlusion for stroke prevention in atrial fibrillation multicenter experience with the AMPLATZER Cardiac Plug. Eurolntervention. 2016;11:1170-9.

35. Gillinov AM, Gelijns AC, Parides MK, et al. Surgical ablation of atrial fibrillation during mitral-valve surgery. N Eng/ I Med. 2015:372:1399-409.

36. Jørgensen $\mathrm{HS}$, Nakayama $\mathrm{H}$, Reith J, et al. Stroke recurrence: predictors, severity, and prognosis. The Copenhagen Stroke Study. Neurology. 1997;48:891-5.

37. Matchar DB, Duncan PW, Samsa GP, et al.The Stroke Prevention Patient Outcomes Research Team. Goals and methods. Stroke. 1993;24:2135-42.

38. Ruff CT, Giugliano RP, Braunwald E, et al. Comparison of the efficacy and safety of new oral anticoagulants with warfarin in patients with atrial fibrillation: a meta-analysis of randomised trials. Lancet. 2014;383:955-62.

39. Connolly SJ, Ezekowitz MD, Yusuf S, et al. RELY Steering Committee and Investigators. Dabigatran versus warfarin in patients with atrial fibrillation. N Eng/ J Med. 2009;361:1139-51.

40. Granger $\mathrm{CB}$, Alexander JH, MCMurray JJ, et al. ARISTOTLE Committees and Investigators. Apixaban versus warfarin in patients with atrial fibrillation. N Engl J Med. 2011;365:981-92.

41. Patel MR, Mahaffey KW, Garg I, et al. ROCKET AF Investigators. Rivaroxaban versus warfarin in nonvalvular atrial fibrillation. N Eng/ J Med. 2011;365:883-91.

42. Giugliano RP, Ruff CT, Braunwald E, et al. Investigators EAT. Edoxaban versus warfarin in patients with atrial fibrillation. N Eng/ J Med. 2013;369:2093-104.

43. Healey JS, Connolly SJ, Gold MR, et al. Subclinical atrial fibrillation and the risk of stroke. N Eng/ J Med. 2012;366:120-9.

44. Hart RG, Pearce LA, Rothbart RM, et al. Stroke with intermittent atrial fibrillation: incidence and predictors during aspirin therapy. Stroke Prevention in Atrial Fibrillation Investigators. Am Coll Cardiol. 2000;35:183-7.

45. Mant J, Hobbs FD, Fletcher $K$, et al. Warfarin versus aspirin for stroke prevention in an elderly community population with atrial fibrillation (the Birmingham Atrial Fibrillation Treatment of the Aged Study, BAFTA): a randomised controlled trial. Lancet. 2007;370:493-503. 